\title{
PENGARUH MODEL PEMBELAJARAN DAN GAYA BELAJAR TERHADAP HASIL BELAJAR PESERTA DIDIK KELAS XI MIPA SMAN 2 SOPPENG (STUDI PADA MATERI POKOK ASAM BASA)
}

\author{
Dirsyah Dedi Nugraha, Tabrani Gani ${ }^{1}$, Muhammad Anwar ${ }^{2}$ \\ ${ }^{1,2}$ Dosen Program Pascasarjana Universitas Negeri Makassar \\ Email:dirsyahdn@gmail.com
}

\begin{abstract}
ABSTRAK
Penelitian ini adalah penelitian eksperimen semu yang bertujuan untuk mengetahui adanya pengaruh model pembelajaran dan gaya belajar terhadap hasil belajar peserta didik kelas XI MIPA SMAN 2 Soppeng. Variabel bebas dalam penelitian ini adalah model pembelajaran dan gaya belajar peserta didik, serta variabel terikatnya adalah hasil belajar peserta didik pada materi pokok asam basa. Populasi penelitian ini adalah peserta didik kelas XI MIPA SMAN 2 Soppeng yang berjumlah 7 kelas, sampel penelitian ini ditentukan dengan teknik random sampling yaitu terdiri atas 2 kelas yaitu Kelas XI MIPA 1 (Kelas A) dan XI MIPA 4 (Kelas B). Desain penelitian adalah Faktorial. Data hasil penelitian diperoleh dengan memberikan tes hasil belajar pada materi asam basa berupa post-test yang terdiri dari 30 butir soal pilihan ganda. Teknik analisis data menggunakan analisis statistik deskriptif dan inferensial. Pengujian hipotesis yang dilakukan dengan uji $\mathrm{F}$ (ANOVA) menghasilkan nilai signifikan lebih besar daripada nilai $\alpha(\alpha=0,05)$. Hasil uji hipotesis dengan Uji F membuktikan bahwa terdapat pengaruh model pembelajaran terhadap hasil belajar, terdapat pengaruh gaya belajar terhadap hasil belajar dan terdapat pengaruh interaksi model pembelajaran dan gaya belajar berpengaruh terhadap hasil belajar peserta didik kelas XI MIPA SMAN 2 Soppeng studi pada materi asam basa.
\end{abstract}

Kata kunci: model pembelajran, gaya belajar, hasil belajar.

\begin{abstract}
This study was a quasi-experimental research, which aimed determining the influence of instructional models and learning style learning outcomes of grade XI MIPA student at SMAN 2 in Soppeng. The independent variables in the study were instructional model and students' learning style; whereas, the dependent variable was learning outcomes on acis base material. The study population was a students at grade XI MIPA student at SMAN 2 in Soppeng which consists of 7 classes, and the sample was selected by employing random sampling technique and obtained two classes, namely class XI MIPA 1 as an Class A and XI MIPA 4 as Class B with random sampling technique. Data were obtained by providing students achievement test acid base subject matter in the form of post-test which consists of 30 items multiple choice. Data were analyzed using descriptive and inferential statistical analysis. Hypothesis testing is done by $\mathrm{F}$ test (ANOVA). F-test results proved that learning model gave influence on students' learning, learning style and interaction of instructional model and learning style on students' learning outcomes of grade XI MIPA student at SMAN 2 in Soppeng studied on acid base.
\end{abstract}

Keywords: Instructional model, learning style, learning outcomes. 


\section{PENDAHULUAN}

Proses pembelajaran dalam kelas adalah salah satu tugas guru yang paling utama yang harus dilakukan dalam melaksanakan tugas sebagai pengajar dan sekaligus pendidik. Dalam proses pembelajaran, pendidik (guru) harus benarbenar merencanakan pembelajaran sebaikbaik mungkin sehingga dapat meningkatkan hasil belajar peserta didik. Setiap melaksakan proses pembelajaran dalam kelas kerap menjadi kendala bagi seorang guru diantaranya seorang guru terkadang mengalami kendala untuk mengontrol suasana kelas tetap kondusif dan membuat setiap peserta didik tetap aktif dalam belajar ditinjau dari model pembelajaran yang digunakan. Setiap peserta didik dalam kelas memiliki karakter dan sifat yang berbedabeda sehingga ini bisa jadi salah satu faktor yang harus dihadapi oleh seorang guru untuk mengetahui karakter dan sifat dari peserta didiknya.

Melihat fakta yang ada sekarang, hasil belajar peserta didik di dalam suatu kelas hanya sebagian kecil saja yang dapat dilihat peningkatannya. Itu dapat dipengaruhi oleh beberapa faktor diantaranya, peserta didik itu sendiri yang pada dasarnya tidak mau belajar, jenuh belajar dengan suasana belajar yang membosankan, bahkan dari guru atau pendidik itu sendiri. Guru yang tidak mampu memberikan suasana nyaman dalam belajar di dalam kelas dalam hal ini adalah model pembelajaran yang diterapkan di dalam kelas. Guru juga perlu mengetahui kondisi dan karakteristik peserta didiknya. Karaktertistik yang dimaksud disini adalah gaya belajar.

Seperti yang kita ketahui bahwa hasil belajar dari peserta didik dipengaruhi oleh beberapa faktor salah satunya adalah gaya belajar peserta didik. Gaya belajar yang dimaksud adalah gaya belajar kinestetik, gaya belajar visual dan gaya belajar audiotorial. Mengenal karakteristik belajar setiap peserta didik di kelas merupakan salah satu bagian dari rana kompetensi pedagogik yang harus dimiliki oleh guru.
Oleh karena itu sebelum guru mengajar dalam kelas seharusnya sudah mengenal lebih dahulu karakteritik belajar dari masing-masing peserta didiknya, khususnya gaya belajar mereka. Sehingga guru tersebut akan lebih efektif dalam memilih model pembelajaran yang akan digunakan.

Banyak faktor yang dapat mempengaruhi seorang anak untuk belajar salah satunya adalah cara anak tersebut belajar (gaya belajar). Ada faktor lain yang dapat mempengaruhi hasil belajar peserta didik salah satunya adalah model pembelajaran yang digunakan dalam kelas saat melangsungkan proses pembelajaran.

Model pembelajaran yang diterapkan guru di dalam kelas juga sangat berpengaruh pada hasil belajar peserta didik. Seperti yang diketahui model pembelajaran yang paling sering dan umum digunakan adalah model pembelajaran langsung. Tidak adanya variasi penggunaan model pembelajaran dalam kelas menyebabkan peserta didik jenuh belajar dalam kelas. Terkhusus mata pelajaran kimia di Sekolah Menengah Atas merupakan salah satu mata pelajaran yang cukup rumit dan susah dipahami jika tidak menggunakan model ataupun metode pembelajaran yang sesuai dengan materi yang akan disampaikan. Materi asam basa dan garam adalah materi tentang senyawasenyawa yang berada disekitar kita yang perlu diketahui. Materi asam basa dan garam yang penuh dengan teori-teori dan perhitungan, jika tidak dijelaskan dengan baik ditunjang dengan model dan metode pembelajaran yang sesuai dan suasana kelas baik pula, maka akan susah ditangkap oleh peserta didik, sehingga guru harus menggunakan model pembelajaran yang sesuai sehingga dapat mempengaruhi hasil belajar peserta didik.

Penggunaan model pembelajaran harus disesuaikan dengan materi yang akan disampaikan ke peserta didik dan menciptakan suasana belajar yang menyenangkan sehingga dapat meningkatkan hasil belajar peserta didik. Salah satu model pembelajaran yang 
menunjang adalah model pembelajaran kooperatif dimana model ini lebih menekankan interaksi antar peserta didik. Dari sini peserta didik akan melakukan komunikasi aktif dengan peserta didik lain, adanya komunikasi tersebut diharapkan peserta didik dapat menguasai materi pelajaran dengan mudah karena terkadang ada peserta didik lebih mudah memahami penjelasan dari kawannya dibandikan mendengarkan penjelasan dari guru, itu dikarenakan cara penyampaian antar peserta didik lebih nyaman. Selain itu, beberapa penelitian juga menunjukkan bahwa pembelajaran kooperatif memiliki pengaruh terhadap hasil belajar peserta didik. Salah satu tipe dari model pembelajaran kooperatif yang bisa digunakan dan selaras dengan materi pelajaran asam basa dan garam adalah model pembelajaran kooperatif tipe Snowball Throwing.

Model pembelajaran kooperatif tipe Snowball Throwing merupakan salah satu modifikasi dari teknik Tanya jawab yang menitikberatkan pada kemampuan peseta didik untuk merumuskan pertanyaan yang akan dikemas dalam sebuah permainan yang menarik yaitu saling melempar bola salju (snowball throwing) yang berisikan pertanyaan kepada sesame temannya. Sehingga informasi dari peserta didik satu dapat tersampaikan dengan jelas ke peserta didik yang lain dan mudah dipahami serta tercipta suasana belajar yang dinamis dan menyenangkan bagi peserta didik tersebut untuk belajar. Berdasarkan hasil penelitian oleh Rasyid,M. \& Side, S. (2013) menunjukkan bahwa penggunaan model pembelajaran kooperatif tipe snowball throwing peserta didik kelas XI SMA N 1 Bajeng kabupaten Gowa dapat meningkatkan kualitas dan hasil belajar peserta didik. Dapat dilihat dari nilai posttest (yang kelas control yang diajar dengan menggunakan model pembelajaran langsung) nilai tertinggi 80, sedangkan nilai terendah adalah 36, sedangkan untuk kelas eksperimen (yang diajar dengan menggunakan model pembelajaran kooperatif tipe snowball throwing) nilai tertinggi 84 dan nilai terendah 40 . Berdasarkan hal tersebut untuk melihat perkembangan peserta didik dalam belajar dapat diliat dari hasil belajar sehingga perlu memerhatikan penggunaan model pembelajaran yang akan digunakaan saat mengajar di dalam kelas. Penggunaan model pembelajaran kooperatif tipe snowball throwing mampu meningkatkan hasil belajar peserta didik dengan melihat dari gaya belajar mereka. Karena dengan menyesuaikan gaya belajar dengan model pembelajaran yang aktif dinamis seperti snowball throwing, diharapkan peserta didik termotivasi, lebih aktif dalam belajar sehingga dapat meningkatkan hasil belajar.

Berdasarkan hasil observasi di SMAN 2 Soppeng pada tanggal 4 September 2017, materi asam basa dan garam merupakan materi yang cukup rumit. Itu dikarenakan pada materi asam basa terdapat banyak konsep maupun teori yang harus peserta didik kuasai dan pahami. Proses pembelajaran yang baik adalah proses pembelajaran yang dapat mengaktifkan peserta didik di dalam kelas sehingga dapat meningkatkan suasana belajar yang nyaman dan meningkankan hasil belajar peserta didik tersebut. Kesulitas tersebut diakui oleh beberapa peserta didik kelas XI dan salah satu guru kimia di sekolah tersebut. Berdasarkan hasil belajar peserta didik yang diperolah pada materi Asam basa menunjukkan hasil yang kurang memuaskan karena persentase tingkat ketuntasan peserta didik adalah $40 \%$ sedangkan standar ketuntasan kompetensi minimal yang diterapkan dalam sekolah tersebut adalah 75\% (Perangkat Pembelajaran SMAN 2 Soppeng 2016-2017).

Adanya interaksi peserta didik dalam belajar, kemudian guru memberikan bimbingan yang rutin terhadap peserta didiknya dalam belajar dengan melihat dari sisi gaya belajarnya dengan menerapkan model pembelajaran yang sesuai dengan gaya belajar mereka, dalam situasi ini diharapkan hasil belajar peserta didik dalam belajar dapat meningkat. 
Berdasarkan latar belakang masalah tersebut di atas, maka rumusan masalah dalam penelitian ini adalah: (1) Apakah ada pengaruh model pembelajaran terhadap hasil belajar peserta didik kelas XI MIPA SMAN 2 Soppeng studi pada materi pokok asam basa? (2) Apakah ada pengaruh gaya belajar terhadap hasil belajar peserta didik kelas XI MIPA SMAN 2 Soppeng studi pada materi pokok asam basa? (3) Apakah ada pengaruh interaksi model pembelajaran dan gaya belajar dalam mempengaruhi hasil belajar peserta didik kelas XI MIPA SMAN 2 Soppeng studi pada materi pokok asam basa?

Berdasarkan rumusan masalah di atas, maka tujuan dari penelitian ini adalah: (1) Untuk mengetahui ada pengaruh model pembelajaran terhadap hasil belajar peserta didik kelas XI MIPA SMAN 2 Soppeng studi pada materi pokok asam basa (2) Untuk mengetahui ada pengaruh gaya belajar terhadap hasil belajar peserta didik kelas XI MIPA SMAN 2 Soppeng studi pada materi pokok asam basa (3) Untuk mengetahui ada pengaruh interaksi model pembelajaran dan gaya belajar dalam mempengaruhi hasil belajar peserta didik kelas XI MIPA SMAN 2 Soppeng studi pada materi pokok asam basa.

\section{METODE PENELITIAN}

Penelitian ini merupakan jenis penelitian eksperimen semu (Quasi Experimental). Penelitian ini akan melihat hubungan model pembelajaran yang merupakan model pembelajaran langsung dan model pembelajaran kooperatif tipe snowball throwing dengan gaya belajar terhadap hasil belajar peserta didik dengan menggunakan desain penelitian faktorial seperti pada tabel 3.1 .

Tabel 3.1 Desain Penelitian Faktorial

\begin{tabular}{|c|c|c|c|}
\hline \multirow{2}{*}{$\begin{array}{c}\text { Model } \\
\text { Pembelajaran }\end{array}$} & \multicolumn{3}{|c|}{ Gaya Belajar } \\
\cline { 2 - 4 } & B1 & B2 & B3 \\
\hline A1 & A1B1 & A1B2 & A1B3 \\
\hline A2 & A2B1 & A2B2 & A2B3 \\
\hline
\end{tabular}

Keterangan :
A1 : Model Pembelajaran Langsung
(Direct Instruction)
A2 : Model Pembelajaran Kooperatif
Tipe Snowball Throwing
B1 : Gaya Belajar Kinestetik
B2 : Gaya Belajar Visual
B3 : Gaya Belajar Auditorial

A1B1 : Hasil belajar Model Pembelajaran

Langsung dan Gaya Belajar

Kinestetik

A1B2 : Hasil belajar Model Pembelajaran

Langsung dan Gaya Belajar Model

Pembelajaran Langsung dan

Gaya Belajar Visual

A1B3 : Hasil belajar Model Pembelajaran

Langsung dan Gaya Belajar Model

Pembelajaran Langsung dan

Gaya Belajar Auditorial

Variabel pada penelitian ini terdiri dari variabel bebas dan variabel terikat. Variabel bebas dalam penelitian ini yaitu model pembelajaran yang terdiri dari model pembelajaran langsung dan model pembelajaran kooperatif tipe snowball throwing serta gaya belajar peserta didik. Variabel terikat dalam penelitian ini adalah hasil belajar peserta didik.

Populasi dalam penelitian ini adalah Populasi dalam penelitian ini adalah Seluruh kelas XI (sebelas) MIPA SMAN 2 Soppeng pada tahun pelajaran 2017/2018 yang terdiri dari 7 Kelas dengan jumlah peserta didik sebanyak 215 orang. Sampel dalam penelitian ini ditentukan dengan teknik random sampling yaitu mengambil dua kelas dari 7 kelas secara acak yaitu Kelas A (XI MIPA 1) yang terdiri atas 26 orang dan Kelas B (XI MIPA 4) yang terdiri dari 26 orang.

Data yang diperoleh dari hasil penelitian akan dianalisis dengan 
menggunakan analisis statistik deskriptif dan analisis statistik inferensial.

1. Analisis Statistik Deskriptif

$$
\text { Analisis statistik deskriptif }
$$

digunakan untuk mendeskriptifkan atau memberikan gambaran umum data yang diperoleh yaitu model pembelajaran dan gaya belajar peserta didik. Pengolahan data dibuat table frekuensi, rata-rata, standar deviasi untuk mendeskripsikan karakteristik masing-masing variabel penelitian digunakan aplikasi Statistikal Package For Social Science (SPSS) 23 for windows. Untuk menentukan gambaran hasil belajar dari model pembelajaran dan gaya belajar peserta didik yaitu dengan menggunakan angket penilaian gaya belajar gaya belajar dapat ditentukan dengan melihat total nilai yang dominan dari ketiga karateristik gaya belajar yang diberikan. Sedangkan hasil belajar peserta didik yang diperoleh dari sebuah tes hasil belajar yang telah diberikan.

2. Analisis Statistik Inferensial

Teknik analisis inferensial digunakan untuk menguji hipotesis penelitian, dalam hal ini digunakan program aplikasi statistik SPSS versi 22. Sebelum uji hipotesis, terlebih dahulu dilakukan uji normalitas dan uji homogenitas.

\section{HASIL DAN PEMBAHASAN}

\section{Hasil Penelitian}

a. Deskripsi Hasil Belajar Peserta Didik Kelas A dan Kelas B

Hasil Penelitian yang disajikan adalah deskripsi atau penggambaran hasil belajar peserta didik kelas A dan kelas B.

Tabel 4.1 Nilai Statistik Deskriptif Hasil Belajar Peserta didik

\begin{tabular}{lll}
\hline Statistik & \multicolumn{2}{c}{ Nilai Statistik } \\
\cline { 2 - 3 } Kelas A & \multicolumn{1}{c}{ Kelas B } \\
(Model & (Model \\
Pembelajaran & Pembelajaran \\
Kooperatif Tipe & Langsung) \\
Snowball Throwing) \\
\hline
\end{tabular}

\begin{tabular}{lcc}
\hline Jumlah sampel & 26 & 26 \\
Nilai terendah & 60 & 33 \\
Nilai tertinggi & 86 & 80 \\
Nilai rata-rata & 72.96 & 63.58 \\
Modus & 77 & 57 \\
Median & 73 & 61.50 \\
Varians & 57.72 & 108.81 \\
Standar Daviasi & 7.59 & 10.43 \\
(S) & & \\
\hline
\end{tabular}

Tabel 4.2 Kriteria Ketuntasan Hasil Belajar Peserta Didik

\begin{tabular}{|c|c|c|c|c|c|}
\hline \multirow[t]{2}{*}{$\begin{array}{c}\text { Nil } \\
\text { ai }\end{array}$} & \multirow[t]{2}{*}{$\begin{array}{c}\text { Kriteria } \\
\text { Ketuntas } \\
\text { an }\end{array}$} & \multicolumn{2}{|c|}{$\begin{array}{c}\text { Kelas A } \\
\text { (Model } \\
\text { Pembelajaran } \\
\text { Kooperatif Tipe } \\
\text { Snowball } \\
\text { Throwing) }\end{array}$} & \multicolumn{2}{|c|}{$\begin{array}{c}\text { Kelas B } \\
\text { (Model } \\
\text { Pembelajaran } \\
\text { Langsung) }\end{array}$} \\
\hline & & $\begin{array}{l}\text { Frekue } \\
\text { nsi }\end{array}$ & $\begin{array}{l}\text { Persent } \\
\text { ase }\end{array}$ & $\begin{array}{l}\text { Frekue } \\
\text { nsi }\end{array}$ & $\begin{array}{l}\text { Persent } \\
\text { ase }\end{array}$ \\
\hline $\begin{array}{c}\geq \\
75\end{array}$ & Tuntas & 12 & $46 \%$ & 7 & $27 \%$ \\
\hline $\begin{array}{c}< \\
75\end{array}$ & $\begin{array}{l}\text { Tidak } \\
\text { tuntas }\end{array}$ & 14 & $54 \%$ & 19 & $73 \%$ \\
\hline
\end{tabular}

\begin{tabular}{|c|c|c|}
\hline \multirow{3}{*}{ Indikator } & $\begin{array}{c}\text { Kelas A } \\
\text { (Model Pembelajaran } \\
\text { Kooperatif Tipe Snowball } \\
\text { Throwing) }\end{array}$ & $\begin{array}{c}\text { Kelas B } \\
\text { (Model } \\
\text { Pembelajaran } \\
\text { Langsung) }\end{array}$ \\
\cline { 2 - 3 } & Persentase (\%) & Persentase (\%) \\
\hline 1 & 70 & 72 \\
\hline 2 & 69 & 75 \\
\hline 3 & 74 & 72 \\
\hline 4 & 84 & 58 \\
\hline 5 & 65 & 47 \\
\hline 6 & 63 & 64 \\
\hline 7 & 71 & 58 \\
\hline 8 & 61 & 75 \\
\hline 9 & 75 & 56 \\
\hline 10 & 69 & 62 \\
\hline
\end{tabular}

Keterangan :

Indikator 1 : Mendefenisikan asam basa menurut Arrhenius

Indikator 2 : Mendefenisikan pengertian 
asam basa menurut Bronsted-

Lowry

Indikator 3 : Menuliskan persamaan reaksi asam dan basa menurut Bronsted-Lowry dan menunjukkan pasangan asam dan basa konjugasi

Indikator 4 : Mendefenisikan pengertian asam basa menurut Lewis

Indikator 5 : Mengidentifikasi sifat larutan asam dan basa dengan indikator.

Indikator 6 : Memperkirakan $\mathrm{pH}$ suatu larutan yang tidak dikenal berdasarkan hasilpengamatan trayek perubahan warna berbagai indikator asam dan basa

Indikator 7 : Menjelaskan pengertian kekuatan asam dan menyimpulkan hasil pengukuran $\mathrm{pH}$ dari beberapa larutan asam dan basa yang konsentrasinya sama.

Indikator 8 : Menghubungkan kekuatan asam atau basa dengan

derajat

pengionan $(\alpha)$ dan tetapan asam $(\mathrm{Ka})$ atau tetapan basa $(\mathrm{Kb})$

Indikator 9 : Menghitung $\mathrm{pH}$ larutan asam atau basa yang diketahui konsentrasinya.

Indikator 10 : Menjelaskan penggunaan konsep $\mathrm{pH}$ dalam lingkungan.

Diagram 4.1 Persentase Pencapaian Tiap Indikator Kelas A dan Kelas B

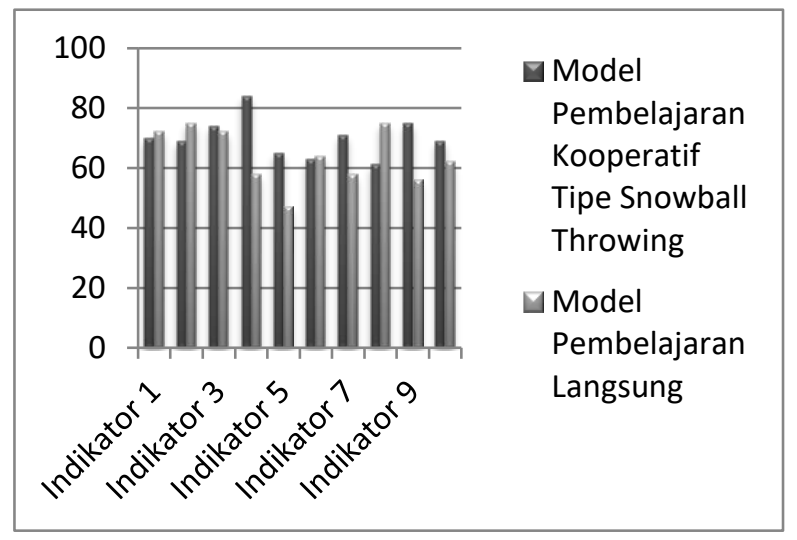

Tabel 4.4 Data Karakteristik Gaya Belajar Peserta Didik

\begin{tabular}{|c|c|c|}
\hline $\begin{array}{c}\text { Gaya } \\
\text { Belajar }\end{array}$ & $\begin{array}{c}\text { Kelas A } \\
\text { (Model Pembelajaran } \\
\text { Kooperatif Tipe } \\
\text { Snowball Throwing) } \\
\text { (Orang) }\end{array}$ & $\begin{array}{c}\text { Kelas B } \\
\text { (Model } \\
\text { Pembelajaran } \\
\text { Langsung) } \\
\text { (Orang) }\end{array}$ \\
\hline Kinestetik & 11 & 13 \\
\hline Visual & 7 & 7 \\
\hline Auditorial & 8 & 6 \\
\hline
\end{tabular}

Tabel 4.5 Ketuntasan Peserta Didik Berdasarkan Gaya Belajar

\begin{tabular}{|c|c|c|c|c|}
\hline \multirow{2}{*}{ Gaya Belajar } & $\begin{array}{r}\text { Kelas A } \\
\text { (Model Pembelajaran } \\
\text { Kooperatif Tipe } \\
\text { Snowball Throwing) } \\
\text { (Orang) }\end{array}$ & $\begin{array}{r}\text { Kelas B } \\
\text { (Model Pembelajaran } \\
\text { (Ongung) }\end{array}$ \\
\cline { 2 - 5 } & Tuntas & $\begin{array}{r}\text { Tidak } \\
\text { tuntas }\end{array}$ & Tuntas & $\begin{array}{c}\text { Tidak } \\
\text { tuntas }\end{array}$ \\
\hline Kinestetik & 4 & 7 & 4 & 9 \\
\hline Visual & 5 & 2 & 2 & 5 \\
\hline Auditorial & 3 & 5 & 2 & 4 \\
\hline JUMLAH & 12 & 14 & 8 & 18 \\
\hline
\end{tabular}

Tabel 4.6 Hasil Belajar Peserta Didik Berdasarkan Hubungan Model Pembelajaran dan Gaya Belajar.

\begin{tabular}{|c|c|c|c|c|}
\hline \multirow{2}{*}{$\begin{array}{c}\text { Model } \\
\text { Pembelajaran }\end{array}$} & \multicolumn{3}{|c|}{ Gaya Belajar } & \multirow[t]{2}{*}{ Total } \\
\hline & Kinestetik & Visual & Auditorial & \\
\hline \multirow{3}{*}{$\begin{array}{l}\text { Snowball } \\
\text { Throwing }\end{array}$} & $\mathrm{N}: 11$ & $\mathrm{~N}: 7$ & $\mathrm{~N}: 8$ & $\mathrm{~N}: 26$ \\
\hline & $\begin{array}{l}\text { Rata-rata : } \\
72\end{array}$ & $\begin{array}{l}\text { Rata-rata } \\
: 78\end{array}$ & $\begin{array}{l}\text { Rata-rata: } \\
70\end{array}$ & $\begin{array}{l}\text { Rata- } \\
\text { Rata: } \\
72.96\end{array}$ \\
\hline & S : 7.48 & $\begin{array}{l}\text { S : } \\
5.29\end{array}$ & S : 7.19 & $\begin{array}{ll}S \quad 7.59\end{array}$ \\
\hline \multirow{3}{*}{$\begin{array}{l}\text { Pembelajaran } \\
\text { Langsung }\end{array}$} & $\mathrm{N}: 13$ & $\mathrm{~N}: 7$ & $\mathrm{~N}: 6$ & $\mathrm{~N}: 26$ \\
\hline & $\begin{array}{l}\text { Rata-rata : } \\
61\end{array}$ & $\begin{array}{l}\text { Rata-rata } \\
: 64\end{array}$ & $\begin{array}{l}\text { Rata-rata: } \\
68\end{array}$ & $\begin{array}{l}\text { Rata- } \\
\text { Rata: } \\
63.58\end{array}$ \\
\hline & $S: 10.14$ & $\begin{array}{l}\text { S : } \\
11.56\end{array}$ & S : 10.19 & $\mathrm{~S}: 10.43$ \\
\hline \multirow{3}{*}{ Total } & $\mathrm{N}: 24$ & $\begin{array}{ll}\mathrm{N} & : 14\end{array}$ & $\mathrm{~N}: 14$ & \\
\hline & $\begin{array}{l}\text { Rata-rata : } \\
66.25\end{array}$ & $\begin{array}{l}\text { Rata-rata } \\
: 71.14\end{array}$ & $\begin{array}{l}\text { Rata-rata } \\
: 68.85\end{array}$ & \\
\hline & $S: 11.23$ & $S: 17.95$ & $S: 17.19$ & \\
\hline
\end{tabular}


Diagram 4.2. Hasil Belajar Peserta Didik Berdasarkan Hubungan Model Pembelajaran dan Gaya Belajar

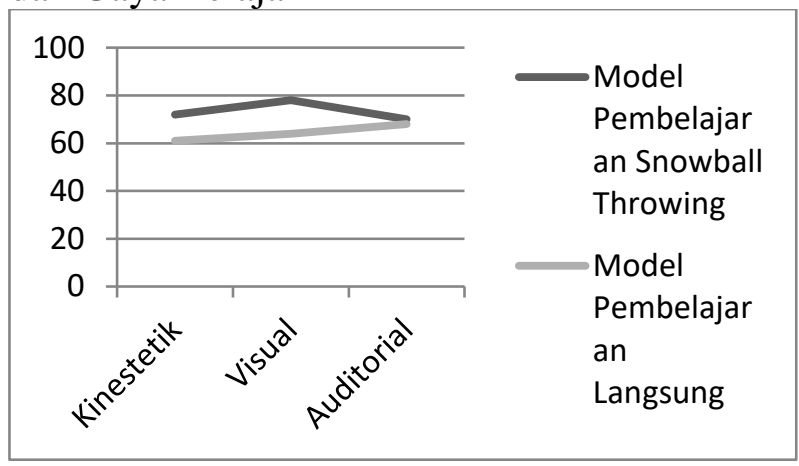

b. Hasil Pengujian Hipotesis

Tabel 4.7 Hasil Pengolahan Uji Hipotesis

\begin{tabular}{|l|r|r|}
\hline \multicolumn{1}{|c|}{ Variabel } & \multicolumn{1}{c|}{ Nilai F } & Nilai Signifikan. \\
\hline Gaya Belajar & .612 & .657 \\
\hline $\begin{array}{l}\text { Model } \\
\text { Pembelajaran }\end{array}$ & 13.889 & .001 \\
\hline $\begin{array}{l}\text { Model } \\
\text { Pembelajaran*Gaya } \\
\text { Belajar }\end{array}$ & 14.007 & .000 \\
\hline
\end{tabular}

\section{Pembahasan}

\section{a. Pengaruh Model Pembelajaran terhadap Hasil Belajar}

Setelah melalui proses pengolahan data dengan menggunakan SPSS 23 didapatkan nilai signifikan sebesar 0.001 dan nilai $F$ adalah 13.889. Kriteria pengujian, $\mathrm{H}_{0}$ ditolak jika nilai signifikansi $<\alpha=0,05$ dan $\mathrm{H}_{0}$ diterima jika nilai signifikansi $>\alpha=0,05$ Berdasarkan data yang diperolah, nilai signifikan $0.001<0.05$ yang artinya $\mathrm{H}_{0}$ di tolak $\mathrm{H}_{1}$ diterima. Dengan demikian terdapat pengaruh model pembelajaran terhadap hasil belajar peserta didik kelas XI MIPA SMAN 2 Soppeng pada materi pokok asam basa. Peserta didik yang aktif secara dinamis didalam kelas yang dibelajarkan model pembelajaran kooperatif tipe snowball throwing membuat hasil belajar mereka lebih tinggi dibandingkan kelas yang dibelajarkan dengan menggunakan model pembelajaran langsung. Itu terjadi karena peserta didik lebih menyukai suasana belajar yang dinamis yang menyenangkan sehingga aktif dalam proses pembelajar dalam kelas.

\section{b. Pengaruh Gaya Belajar terhadap Hasil Belajar}

Setelah melalui proses pengolahan data dengan menggunakan SPSS 23 diperoleh nilai signifikan 0.657 dan nilai $\mathrm{F}=$ 0.612. Kriteria pengujian, $\mathrm{H}_{0}$ ditolak jika nilai signifikansi $<\alpha=0,05$ dan $\mathrm{H}_{0}$ diterima jika nilai signifikansi $>\alpha=0,05$. Berdasarkan data tersebut, nilai signifikan $0.657>0.05$ yang artinya $\mathrm{H}_{0}$ diterima, $\mathrm{H}_{1}$ ditolak. Dengan demikian tidak terdapat pengaruh gaya belajar terhadap hasil belajar peserta didik kelas XI MIPA SMAN 2 Soppeng pada materi pokok asam basa. Kelemahan gaya belajar ini adalah keterbatasan waktu di dalam kelas untuk menjelaskan materi secara menyeluruh bagi pendidik dan peserta didik cenderung menunggu penjelasan dari pendidik sehingga mereka tiak kreatif mencari sendiri bahan atau materi pembelajaran jika tidak diwajibkan oleh pendidik untuk memeiliki sumber atau rujukan. Dalam menyikapi berbagai macam mengenai gaya belajar, tentulah harus ditambah dengan logika dan kebudayaan cara kerja kita, dan yang paling penting dari semuanya adalah suatu cara kerja otak kita yang mana dalam hal ini kita sebut dengan modalitas belajar. Secara singkat, modalitas belajar adalah suatu cara bagaimana otak menyerap informasi yang masuk melalui panca indera secara optimal. Gaya belajar juga harus disesuaikan dengan karakteristik mata pelajaran atau materi yang akan diajarkan sehingga dapat dimanfaatkan nanti dalam proses pembelajaran dalam hal ini mengikutsertakan gaya belajar peserta didik.

\section{c. Interaksi antara Model Pembelajaran dan Gaya Belajar dalam mempengaruhi Hasil Belajar}

Setelah melalui proses pengolahan data dengan menggunakan SPSS 23 diperoleh nilai signifikan 0.06 dan nilai $\mathrm{F}=0.76$. Kriteria pengujian, $\mathrm{H}_{0}$ ditolak jika nilai 
signifikansi $<\alpha=0,05$ dan $\mathrm{H}_{0}$ diterima jika nilai signifikansi $>\alpha=0,05$ Berdasarkan data tersebut, nilai signifikan $0.000<0.05$ yang artinya $\mathrm{H} 1$ diterima, H0 ditolak. Dengan demikian terdapat pengaruh interaksi model pembelajaran dan gaya belajar terhadap hasil belajar peserta didik kelas XI MIPA SMAN 2 Soppeng pada materi pokok asam basa. Hasil belajar peserta didik berdasarkan hubungan model pembelajaran dan gaya belajar diperoleh hasil belajar pada kelas yang dibelajarkan dengan model pembelajaran kooperatif tipe snowball throwing memiliki nilai rata-rata yang tinggi yaitu 72 dibandingkan dengan kelas yang dibelajarkan dengan menggunakan model pembelajaran langsung yaitu 61. Hasil belajar gaya belajar visual pada kelas model pembelajaran kooperatif tipe snowball throwing juga memiliki nilai rata-rata lebih tinggi yaitu 78 dibandingkan dengan kelas yang menggunakan model pembelajaran langsung yaitu 64. Sama halnya dengan gaya belajar auditorial pada model pembelajaran kooperatif tipe snowball throwing memiliki nilai rata-rata lebih tinggi yaitu 70 dibandingkan dengan kelas yang dibelajarkan dengan model pembelajaran langsung. Berdasarkan data tersebut dapat disimpulkan bahwa pada gaya belajar visual lebih cocok dengan model pembelajaran kooperatif tipe snowball throwing.

\section{SIMPULAN DAN SARAN}

1. Terdapat pengaruh model pembelajaran terhadap hasil belajar peserta didik kelas XI MIPA SMAN 2 Soppeng pada materi pokok asam basa.

2. Tidak terdapat pengaruh gaya belajar terhadap hasil belajar peserta didik kelas XI MIPA SMAN 2 Soppeng pada materi pokok asam basa.

3. Terdapat pengaruh interaksi model pembelajaran dan gaya belajar terhadap hasil belajar peserta didik kelas XI MIPA SMAN 2 Soppeng pada materi pokok asam basa.

\section{DAFTAR RUJUKAN}

Afandi,M S.P., Chamalah, E., Oktarina Puspita Wardani, S.P., Gunarto, H. \& Hum, M. 2013. MODEL DAN METODE PEMBELAJARAN. Semarang: UNISSULA.

Azizan, M.T., Mellon, N., Ramli, R.M. \& Yusup, S. 2018. Improving teamwork skills and enhancing deep learning via development of board game using cooperative learning method in Reaction Engineering course. Education for Chemical Engineers, 22(Supplement C): 1-13.

Depotter, B. \& Rearoon, M.S. 2008. Quantum Teaching. Bandung: Kaifa PT Mizan Pustaka.

Emerson, T.L.N., English, L. \& McGoldrick, K. 2016. Cooperative learning and personality types. International Review of Economics Education, 21(Supplement C): 21-29.

Fauzi, H. 2014. Pengertian dan LangkahLangkah Model Pembelajaran Snowball Throwing. http://wawasanpendidikan.com/ pengertian-dan-langkahlangkahmodel-pembelajaran-snowballthrowing/ 14 November 2017.

Ghufron, N. \& Riswanita, R. 2010. Gaya Belajar Kajian Teoritik. Yogyakarta: Pustaka Belajar.

Hasyim, M., Muris, M. \& Yani, A. 2014. Pengaruh Model Pembelajaran dan Gaya Belajar terhadap Keterampilan Proses Sains Peserta Didik Kelas VII SMP Negeri 30 Makassar. Jurnal Riset dan Kajian Pendidikan Fisika, 1(2): 52.

Maric, M., Penger, S., Todorovic, I., Djurica, N. \& Pintar, R. 2015. Differences in Learning Styles: A comparison of Slovenian Universities. Procedia - Social and Behavioral Sciences, 197: 175-183.

Mulyono, A. 2003. Pendidikan Bagi Anak Berkesulitan Belajar. 1st ed. Jakarata: Rineka Cipta. 
Navarro-Pablo, M. \& Gallardo-Saborido, E.J. 2015. Teaching to Training Teachers through Cooperative Learning. Procedia - Social and Behavioral Sciences, 180(Supplement C): 401-406.

Rasyid, M. \& Side, S. 2013. Pengaruh Penerapan Pembelajaran Snowball Throwing terhadap Hasil Belajar Peserta didik Kelas X SMAN I Bajeng Kab. Gowa (Studi pada Materi Pokok Senyawa Hidrokarbon). CHEMICA, 12(2): 69-76.

Sahabuddin, H. 2007. Belajar dan Mengajar. Makassar: Universitas Negeri Makassar.

Sembiring, R.H. 2012. Efektivitas Metode Pembelajaran Snowball Throwing Terhadap Kemampuan Menganalisis Nilai-Nilai Religius Novel Munajat Cinta II" Karya Taufiqurrahman AlAzizy oleh Peserta didik Kelas XI Madrasah Aliyah Swasta Proyek Univa Medan Tahun Pembelajaran 2010/2011. Asas: Jurnal Sastra, 1(1).

Slavin, R.E. 2008. Cooperative Learning Teori, Riset dan Praktik. 3rd ed. Bandung: Nusa Media.

Sudjana, N. 2010. Penilaian Proses Belajar Mengajar. 1st ed. Bandung: Remaja Rosdakarya.

Sudrajat, A. 2011. Kurikulum dan Pembelajaran dalam Paradigma Baru. Yogyakarta: Paramitra.

Suyono \& Hariyanto. 2011. Belajar dan Pembelajaran: Teori dan Konsep Dasar. Surabaya: Rosda.

Švarcová, E. \& Jelínková, K. 2016. Detection of Learning Styles in the Focus Group. Procedia - Social and Behavioral Sciences, 217: 177-182.

Tanta, T. 2010. Pengaruh Gaya Belajar Terhadap Hasil Belajar Mahapeserta Didik Pada Mata Kuliah Biologi Umum Program Studi Pendidikan Biologi Universitas Cenderawasih
(The Impact of Learning Style towards Studentsâ $€^{\mathrm{TM}}$ Study Achievement on the Subject of General Biology, of Biolog. Jurnal Kreatif: Jurnal Kependidikan Dasar, 1(1).

Trianto. 2009. Mendesain Model Pembelajaran Inovatif. 6th ed. Jakarta: Jakarta Putra Grafika.

Triyana, N. 2012. Perbandingan Pengaruh Pembelajaran Kooperatif Tipe STAD (Student Team Achievement Division) dan Konvensional terhadap Hasil Belajar Peserta didik Kelas XI IPA SMAN 9 Makassar. 1st ed. Makassar: Universitas Negeri Makassar.

Vizeshfar, F. \& Torabizadeh, C. 2017. The effect of teaching based on dominant learning style on nursing students' academic achievement. Nurse Education in Practice, 28: 103-108.

Widodo, R. 2009. Model Pembelajaran Snowball Throwing. Jakarta: Bumi Aksara. 